\title{
An Analysis of Latent Factors Influencing Gambia-Senegal Relations beyond Colonial Dichotomy
}

\author{
Awosusi Oladotun Emmanuel ${ }^{1 *}$ Muhammed Lenn ${ }^{2}$ \\ 1. Department of International Relations and Strategic Studies, Legacy University, The Gambia \\ 2. Department of Diplomacy and International Relations, Management Development Institute, P.O. Box \\ 2553, Serrekunda, The Gambia
}

\begin{abstract}
The Gambia and Senegal was 'one people' separated through the instrument of the 1889 Anglo-French convention which partitioned the people between Britain and France. In spite of the colonial dichotomy which portrayed the blood neighbours as different people, the two states at Independence still see themselves as one and have taken decisive steps to look and relate beyond the legacies of the colonial expedition. Although efforts to foster cooperation and continual friendly relations in terms of political union were threatened and eventually aborted by the colonial legacies because they could not fit into each other politically, partly due to different colonial administrative experience, and this has strained relations between them. Nevertheless, being propelled by some latent factors, the two states still see the possibility and the prime need to forge friendly relations amidst the threatening colonial legacies. Hence, this paper looks into underlying forces and factors that continue to grease the friction between the two states, and help them to forge a common ground politically, socially, economically and otherwise amidst the beckoning challenges.
\end{abstract}

Keywords: Gambia-Senegal Relations, Colonial legacies, Border Conflict, Latent Factors, National Interest.

DOI: $10.7176 / \mathrm{IAGS} / 75-05$

Publication date: August $31^{\text {st }} 2019$

\section{Introduction}

The bilateral relation between Gambia and Senegal is historically phenomena. At independence, the two neighbouring states geared efforts to restore their pre-colonial brotherhood which had been altered by colonial expeditions of 19th to 20th century, during which peoples with homogenous features and history were separated into different nations for perceived political and economic reasons. The desire to address these aged-long colonial legacies dominated the affairs of the two states at independence in the 1960s. They were faced with means and how to better close the gap between them. This necessitated the quest for formal political union in terms of functional integration which eventually led to the merging of two independent countries into a single confederated state of 'Senegambia' (Arnold, 1992). The two separated people had lived as one prior to the coming of Europeans and their relations were largely influenced by their shared culture, language and history which were further strengthened by economic exchanges of diverse kinds. The colonial expeditions altered the pre-colonial relations and separated the 'one people' with distinct homogenous components and identities into two different states. Today, the two countries speak similar indigenous languages with two different official languages; Gambians speak English while Senegalese Speak French.

Given the colonial influence on the two countries, their behaviours, modes of thought and value system took opposite direction, as Gambia took after Britain and Senegal after France, which by implication extends to educational, judicial and political systems in both states. As expected, the colonial arbitrary border created between the two bloods neighbours continued to dot their aged-long friendly relations. Today, the once smooth relations are marred with border conflict turning blood neighbours to enemies (Khan, 2017).

However, the relations between the two blood neighbours took a new turn few years after independence in efforts which culminated into the merging of the two separated independent states into a single state of Senegambia in 1982. In his popular work titled Origins of Alliance, Walt (1987), posited that states facing, or at least have unilaterally perceived that they are about to face, or perhaps have already faced an internal challenge, may seek external support, by forming alliances, in order to deal with the danger. The two states perceived the implication of the colonial dichotomy on the furtherance of their respective interest in their future relations and tend to address it with conscious efforts. The two states formed the Senegambia Confederation, a formal political union that attempted to achieve a "United Senegambia" and redefine the longstanding political polarity and partition caused by colonial expeditions between the two states. Nevertheless, after seven years of failed negotiations on the implementation of the protocol instruments, the Confederation came to an abrupt collapse in 
1989. The collapse of the confederation was due to many factors that centred on different perceptions of the union by the people of the two states.

According to Arnold and David (2008), there were Gambians, and of course Senegalese, who opposed the Confederation on the basis that the two countries were in fact different. These critics saw the Confederation as Senegal's attempt to use ethnic affiliations as an excuse to dominate its smaller neighbour, The Gambia. This view fuelled Gambian nationalist sentiments against the Confederation and paved way for its eventual collapse. As a small country, therefore, perhaps the strategic move for The Gambia, as determined by its geographical situation among other compelling forces, is to forge a qualitative alliance with a relatively larger partner and neighbour, Senegal. The Gambia, emerging from a very difficult and painful period in the early 1980s that saw a coup and fearing that a repeat of the 1981 coup could take place, in the event of which her survival would be at stake, requested Senegal to take care of her security needs. This is partly because the government could no longer trust the Field Force, who instead of loyally protecting the state against any unconstitutional and subversive move, joined ranks with the coup plotters to overthrow it. The coup therefore exposed The Gambia as a country that was very vulnerable internally with no viable and reliable security strategies and mechanisms to protect it. As such, the fate of Gambia lied on the strength of support it gets from beyond its borders. To achieve a strong internal security, it was vital for The Gambia, to forge an alliance with Senegal, the only country that borders it, to protect its national interest as well as ensure its survival.

However, the end of the confederation signalled a new era in relations; there was less concern with cooperation and 'Senegambia' ceased to refer to a process of integration of the two states into one legal entity; it was now a matter of inter-state relations between two coexisting states as two independent states (Jeggan, 2012). The demise of the confederation marked cracks in their relations as border conflict ensued between the two in the same year the confederation collapsed. The period was laced with tensions. But irrespective of the recurrence of political uproar over the border, people in the two countries nurtured a popular belief that they are kinsmen and they have a shared culture. They describe themselves as "one people" and they use kinship metaphors to refer to each other. The two states have made efforts to foster a closer relationship irrespective of recurrent political differences over the border.

There was never a record of armed conflict between Gambia and Senegal over the Casamance border and the two have been experiencing continuities in relations. Given this, this paper tends to explore the underlying factors that continue to plaster the cracks in the walls of Gambia-Senegal relations and propelling the separated states to always be on the same page amidst the threatening and intense border conflict which resulted from the colonial arbitrary demarcation. To fully comprehend the dynamics of the relations and the forces influencing the continuities of the Gambia-Senegal relations, however, there is a need to analyse them in historical perspective. Thus, the succeeding parts are designed in the following ways: the analytical framework of the argument, historical and contemporary appraisal of Gambia-Senegal relations; analysis of the identifiable latent factors influencing the continuities of the relations beyond inherited colonial legacies; The paper concludes with emphasis on means and how to further cement their relations given the unbreakable influencing factors, and draws lessons for other Africa countries.

\section{Analytical Framework}

International Relations describe the totality of interactions between two (bilateral) or more actors (Multilateral) in separate national boundaries. In other words, it describes the relationships that take place between and amongst members of the international community. These include all or any aspects of their relationship such as war, conflict, dispute, separation, alliance, belligerency, settlement, pact, treaties, cooperation, conferences, and organization. However, the crux of this work is hinged on the Realist explanation and understanding of interstate relations. Morgenthau (1948); Carr (1939); Kissinger (1984), among others are the brains in this school. The realists' argument begins with the nature of politics and man. Politics, which principally means the determination of who gets what, when and how, or the authoritative allocation of resources, gives little or no room for morality or friendliness (Lasswel, 1936). Moreover, man is by nature selfish and aggressive, and on a matter that involves the sharing of scarce resources over which all are contending, law and order or moral consciousness would be the last resort. To the realist, Politics is thus the opposite of morality. Talking about morality and law in "politics" therefore implies putting a square peg in a round hole: they do not go together. Thus, the realists are of the opinion that international relations or politics is beyond what could be described or explain in terms of morality. Moreover, realists, argue that the need for survival requires state leaders to distance 
themselves from traditional morality which attaches a positive value to caution, piety and the greater good of human kind (Dunne \& Schmidt 2005:142).

To the realists, there may be anarchy because of three overriding issues that characterize inter-state relation: national interest, national power and military strategy. Indeed, realists place emphasis on these three in their analysis bearing in mind that historical experience in international system has demonstrated these tendencies, and the system continues to show the tendencies. National interest, a set of objectives and goals a nation has articulated as its principal targets in its external relations, is a core factor in international politics. Morgenthau (1966) who has extended the frontiers of political realism in his popular book, Politics among Nations: The Struggle for Power and Peace argues that the main push factor for states in the international community is their uncompromised interest. National interest is not only an end in itself; it is also a means to an end. National power is the ultimate aim of states. Power in this light refers to national values, economic riches, or national wealth and national prestige (influence in international community). Power is the 'currency' of international politics. It has thus becomes an end in itself as well as a means to an end too. With this foundational understanding, the brotherliness claim as the basis for the continuities in Senegal-Gambia relations are worth looking into. The two states have been threatened by colonial dichotomy like other nations in Africa, but they have always opened their doors for dialogue and employed fence-mending diplomacy to ensure continuous relations.

\section{Historical and Contemporary Gambia-Senegal Relations: An Appraisal}

Contacts between the Gambia and Senegal peoples predate colonialism. There were evidential and structured political, cultural, military and economic interchanges between them prior to the coming of Europeans to coast of West Africa sub region. According to Golvin, (1975) the pre-colonial Senegambia inter-state system was characterized with normal and organised communication among all the polities in the system both on the national and popular levels, and diplomatic embassies were exchanged, war were fought, dissidents political factions were given asylum, sporting events and cultural exchanges held, people intermarried, Muslim scholars back and forth to study, and most of all, commercial exchange was constant. He went further that, the modern state Senegal and, with its little Gambia enclave corresponds very closely to the pre-existing interstate system and its already established communication and commercial network. The old unity of the two states based balance of power and commercial interchange was replaced by two entities each bound by separate European commercial and communication networks and political system. Although the colonial adventure faced stiff resistance from the people for almost forty years, European technological superiority provided basis for colonial domination and consequent occupation.

Having seen the evils of the colonial division, attempts to foster cooperation between the separated 'bloodneighbours' started before the two states gained full independence from their respective colonial masters. Considering the geographic, socio-economic and political peculiarities of the two states, sincere moves in form of strategies and discourse on how to create and achieve a socio-economic and political union between the two states after independence were made from 1958. Concerted efforts were geared to work out the approach to and strategies for furthering cooperation, the purpose and objective of such cooperation and what accurate modalities were to be adopted.

Broadly, the Gambia-Senegal relations evolve in phases and it's multidimensional in outlook and approach. The first phase which saw the constitutional process and issues which eventually led to the birth of the two states was the most critical. It coincided with the most intense competition for political power as circumstances pointed to the coming of independence in earnest. The process had commenced since 1954 and became more competitive by the end of the decade. A major reason was the emergence of the Protectorate as a political force to challenge the Colony-restricted politics; the introduction of universal adult suffrage contributed to these new dynamics. The political stakes were higher. In the circumstances, the issue of cooperation and integration between Gambia and Senegal was trapped in the turbulence of national politics. By the end of the period, especially after the negotiations over the UN report in May 1964, it appeared that the functional strategy was the preferred option of The Gambia government, which favoured a compromise "association," which would allow for a more leisurely progression toward closer union. For the Senegalese government, on the other hand, instant integration was favoured, but she decided to go along with the Gambian position in the expectation while noting that, with time, the latter would be won over (Jeggan, 2012).

It is pertinent to surface, however, that neither the British nor the Senegalese government wanted to appear to force The Gambia into such cooperation, but integrating the two areas seemed an obvious means of salvaging the 
economic non-viability of The Gambia, and it would address the arbitrary division established by then 1889 Anglo-French Convention. For the Senegalese, a union would put an end to large-scale smuggling (principally by Senegalese nationals) of cheaper goods from The Gambia into Senegal (Arnold \&David, 2008). Consequently, The Gambia became independent but immediately signed a defence agreement with Senegal, and a formal Treaty of Association was agreed to in April 1967. The signing of the treaty marked another historical phase of the Gambia-Senegal relations. This led to the setting up in 1968 of an Inter-State Ministerial Committee, served by a Senegalese-Gambian Secretariat, charged with promoting further functional cooperation between the two states. That is, mainly to serve as the political and technical body designed to intensify cooperation between the two states through a host of framework protocols and agreements. Consequently, substantive cooperation in a multiplicity of sectors was achieved and 'Senegambia integration' took on real meaning. Both in terms of scope or level, there was a noticeable increase in cooperation activities. Regardless of the measurement employed 'transactions' increased exponentially.

In fact, there were noticeable interactions at all levels and in all areas; amongst the entire populations, technocrats and policy makers, the political leaderships, professionals and business tycoons. Although relations between the two countries sometimes swung mood and went strained particularly in 1969, 1971, and 1974, nevertheless, between 1965 and 1982, about 30 cooperative agreements were signed. In addition, the Organization for the Development of the Gambia River Basin was created in 1978 (Ibid. 2008).

A new order of relation between the two states came in 1980 following the botched 1981 coup in The Gambia, which subsequently led to the establishment of the Senegambia Confederation. A number of protocols, aimed at promoting closer integration between the two countries, were signed between 1982 and 1989, but the Confederation ultimately failed and was formally wound up in October 1989 partly due to differences in a number of areas, particularly in perceptions and expectations as to the end-goal of the union. Following this, relations between the former partners swung mood and subsequently became strained, despite their signing of a new Treaty of Friendship and Cooperation in January 1991, which emphasized the "special relationship" between them. This agreement was very similar to the Treaty of Association of 1967, the position most acceptable to The Gambia, and it allowed for annual meetings of the two heads of state and the creation of a new joint commission to handle matters of common concern. Periodic Senegalese border closures and harassment of Gambian travellers were explained away as anti-smuggling measures by the Dakar authorities. However, most Gambians believed the Senegalese were motivated by pique and a desire to make things economically difficult for the Gambian government, since cross-border trade with Senegal and other neighbouring countries was vital to the Gambian economic survival.

The strained post-confederation relations between the two states saw a military take-over of the government in The Gambia in July 1994 which brought Yahyah Jammeh into power and the end of the Presidency of Abdou Diouf in March 2000. Meanwhile, Diouf had assumed power in Senegal, in 1980, a few months before the botched coup d'état in The Gambia, and built on the foundations for Senegambia cooperation laid down by his predecessor, President Senghor, through the first and second periods. The end of the confederation meant a new era in relations; the tempo for cooperation and "integration" went down. 'Senegambia' ceased to refer to a process of merger of the two states into one legal entity; it was now a matter of inter-state relations between two coexisting states as for any other two independent states (Arnold, 1992 \&Jeggan, 2008).

Having gained political power, President Yahya Jammeh took commendable steps to establish good relations with her neighbours specifically Senegal, but the introduction of tighter control at the Senegalese borders restrictions remained to hinder his plans and such made counter efforts to defuse the tension. Besides, the increasing border tension at Senegal's southern region, Casamance, where Jola ethnic separatists in the Mouvement des Forces Démocratiques de la Casamance continued to pose threat to the Senegal national security, caused the Senegalese authorities to suspect Jammeh's intentions, considering his Jola ethnic background. In the Same vein, the Casamance border conflict left the Senegalese with no option than to stretch hand of friendship to The Gambia considering its security implications, the separatist movement won the heart of The Gambia states to champion her course.

The relations experience between 2000 and 2012 was not totally different from that 1980-1990s. The period denoted the coming into power of President Wade's government in Senegal and its demise. It represented a shift in national interest of the two states. As for Senegal, her central focus was the resolution of the Casamance increasing border issues. For dealing with this preoccupation, it was in the interest of peaceful coexistence that cooperation continues, even if not with the same intensity as in the preceding years. The institutional architecture for organizing such cooperation was of the leanest; in fact, it was non-existent until the formation of the Ministerial Commission and the Consultative Commission (Jeggan, 2012). Perhaps it was because of the new 
form of relationship that the crises that emerged since 2000 were not easily resolved: these included border incidents over transit charges for Senegalese vehicles, the football 'war' between the two national teams, shipment of military hardware from Iran, harassment of Gambian nationals at Dakar airport, etc.

Similarly, the assumption of office by President Sall of Senegal in 2012 marked another phase in the GambiaSenegal relations. Like its predecessors, the new government recognizes the importance of prioritizing Casamance border crises within the framework of inter-state relations with Gambia. Even before the run-off presidential elections in Senegal in March 2012, which resulted in his accession to the presidency, Sall had declared that The Gambia and Guinea Bissau would be the first countries to visit officially if he were victorious. On the imperative of maintaining a good relation with Gambia and other neighbours, President Sall, in his first press interview, noted that "The Gambia and Guinea Bissau were additional grounds for good neighbourliness. To begin with, these countries are our immediate neighbours and we share everything in common, blood ties, culture, language history and everything. Hence, peace and cooperation should exist between and among us" (Freedom Newspaper Online, 2012).

However, during the 22 years rule of the Gambia former president, Yahyah Jammeh which ended with his defeat in the 2016 presidential election, relations between the two states were highly volatile. In early 2016, their shared borders were closed for weeks as a result of a custom dispute, leading to disruption of economic activities in Senegal as Taxis and Lorries that uses the trans-Gambia highway to carry passengers and goods between Casamance, the southern Senegalese province, and other parts of the country could not operate. The fact that Gambia dissidents based in Senegal have been allowed to be more vocal and criticize Jammeh's regime in The Gambia under President Sall's administration contributed to the volatility of their relations. In short, the relations between the two states were further challenged and shaken by the coming to power of Yahya Jammeh who was seen and treated with utmost suspicion mainly because of perceived sympathy for the Casamance rebel movement as well as his inward looking and belligerent politics and policies (Lamin, 2019). Consequently, the Gambia-Senegal relations took a nosedive and reached its lowest ebb during the Jammeh's 22 years rule in The Gambia. This can be seen in the frequent border closures and wars of words against the past and present leaders of Senegal by the Gambia leader, Yahya Jammeh.

Thus, the scheduled 2016 presidential election presented a robust opportunity for the Senegalese government to deploy their diplomatic intrigues, manoeuvres and understanding of international relations against Yayah Jammeh undiplomatic policies which had resorted to somewhat isolationism foreign policies. The Senegalese invoked the power of multilateral diplomacy and put Jammeh in a tight corner thereby making his regime less attractive to the regional states and by extension international community. Consequent upon Jammeh's defeat and Senegalese diplomatic manoeuvres to mobilize international support against him having refused to step down, he was left with the only option of resorting to exile and the newly elected president, Adama Barrow was given national and international recognition.

The birth of the new Gambia in 2017 surfaced a new turn in the Gambia-Senegal relations as the historical friendly relations was rejuvenated once again through series of cooperation agreements signed between the two states and establishment of presidential council to complement Gambia-Senegalese Permanent Secretariat with the aim to further cement the historical bond between the two neighbouring states. Beyond the political and diplomatic cooperation, however, the socio-cultural interactions between and amongst the peoples and economic relations have taken a new order which can be termed to be robust.

\subsection{Cracks and Continuous fence-mending in Gambia-Senegal Relations: The Latent Influencing Factors}

The Gambia-Senegal relations seem to appear in contrast to the popular realist understanding that in international relations, there is neither permanent friend nor enemy, but permanent interest. But in reality, the said smooth relations are embedded in interest which seems mutually beneficial. Since independence, the two states have always made efforts on either side to mend their fences in no time and further smooth relation. Inter-state relations are a function of certain external or internal factors. No state in the international system relates with other states without being conditioned or driven by certain forces. Similarly, the historic inter-state relations between Gambia and Senegal predicated on certain factors. The relations have swung mood on different instances especially after the collapse of the Senegambia confederation. Economic exchange has been marred by border closure on both sides. During Yahya Jammeh's era, the border that further economic relations between the two was closed for weeks to force negotiations and compromise on the part of Senegal. The question therefore, is what are the forces that continue to draw and attract the two neighbours to each other and propel 
them to mend their broken fences and plaster their cracked walls quickly before it totally degenerate into armed border conflict as seen in the case of Casamance? The answer to this is embedded in some latent or underlying forces which revolve around their respective national interest which tends to be mutually reinforcing. Those factors shall be analytically brought to fore here.

\subsection{Senegalese Quest for Regional Hegemony}

Since independence, Senegal has used its diplomatic network, democratic legitimacy and scarce resources to advance a policy of patronage and regional influence in the West African sub-region and Africa as a whole(Foucher,2013). This is in tandem with realist position in international relations that power is the means and end of international relations and politics. That is, every nation uses whatever they have in terms of power to advance their international image and influence. The quest for regional hegemonic influence is unquestionably one of the dominant factors determining the Senegalese foreign relations with its neighbouring states especially Gambia and Guinea-Bissau in the West African Sub-region. Senegal has always appeared as state with the means and motivation to assume a protector role in the sub-region and by extension, the African continent. Apart from being merely a channel for French interest in West Africa, Senegal especially under the leadership of President Abdoulaye Wade has showed interest and politics of patronage hegemonic capacity in West Africa (Foucher, 2013). The Senegalese policy makers understood that the achievement of the Senegalese continental dream of being a regional hegemony is premised on forging good relations with her neighbours. To put this in perspective, the attainment of regional hegemonic influence is a function of Economic and Military dominance and substantial alliance or support, but internally, the state is being faced with separatist struggle at Casamance which is the southern province of Senegal and strategic to the economic survival of the state. By implication, if the Casamance separatist, succeeded in seceding from the Senegalese state, the manifest dream of becoming a regional hegemony would not only be frustrated, but would become moribund. Given the strategic importance of embattled Casamance border to ensuring the Senegalese regional influence, the state is thus left with the only option of deploying all diplomatic calculations and manoeuvres to ensure continual friendly relations with The Gambia considering its strategic importance to Senegal in the case of Casamance border conflict. The map below shows the location of Casamance and how it's being separated from the rest of Senegal by the Gambia.

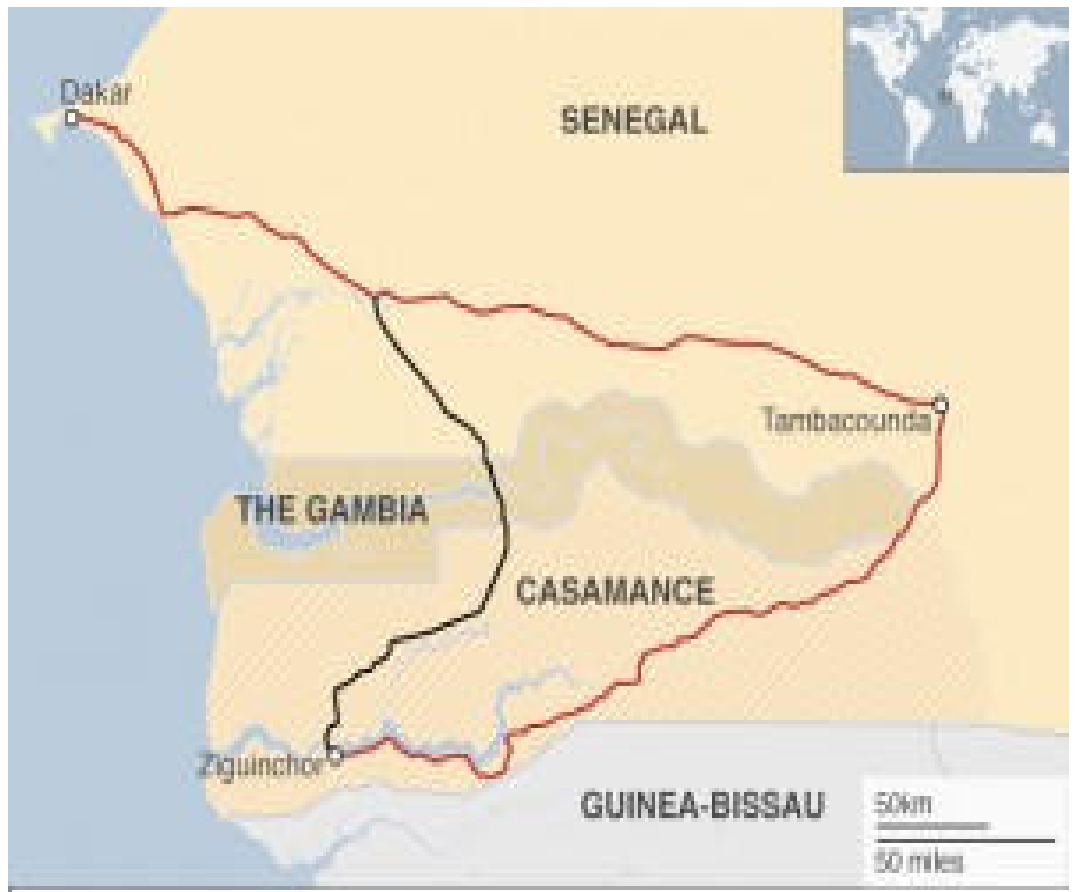

Map Showing Strategic Location of the Gambia and Senegal's Southern region of Casamance. 
Evidently, from the map above it can be seen that Casamance is connected in the east to Senegal, and is separated from the rest of Senegal by the Gambia and such, the Gambia controls and manages both overland and river crossing routes to Casamance, Senegalese restive southern region. Any attempt by Gambia to close its Casamance border implies hard time for the the Senegalese as the people in the southern Senegalese region of Casamance would have to travelled all the way round the Gambia to take Tambacounda route of about 15 hours' drive, instead of Ziguinchor route of just 5 to 6 hours(Ibid.,2016). Ethnically, the principal inhabitants of the region are the Jola ethnic group which equally constitutes $10 \%$ of Gambia population. (World Population Review, 2019)

Considering these factors, Senegal has at all cost avoided violent confrontation with Gambia as it had with other neighbours in spite of its dissatisfaction with Gambia Control of the river crossing routes to Casamance. For instance, in 2010, there was a rare verbal confrontation between the two countries when an arms shipment from Iran was intercepted in Nigeria. The Senegalese government believed the arms shipment which was allegedly destined to The Gambia, was for the Casamance rebels. The Senegalese government nurtures suspicions that The Gambia supports Casamance rebels' secession struggle. The following years, relations between Sall and Jammeh became strained as the former commuted the death penalty, in which two Senegalese inmates were among those executed (BBC News, August, 29, 2012). This was motivated by what many considered as Jammeh's anger over the provision of a safe haven for Gambian dissidents in Dakar. This marked another turning point in SenegalGambia relations. The following years will witness different political strategies by Senegal, including but not limited to taking any opportunity for a regime change in The Gambia. This quest was not unconnected with the multilateral diplomacy of Senegal to oust the hostile Gambia leader, Yahya Jammeh of Jola ethnic group who was perceived of sympathizing with the Casamance rebels.

Thus, during the 2016 general election in Gambia, through diplomatic networks, Senegal ensured Jammeh does not only leave power but that he does not return to his hometown, Kanilia which is a stone throw from Casamance, where he would have been reunited with the militant faction of Movement for Democratic Forces of Casamance (Jeng, 2017:14). Jammeh's defeat in the presidential election dealt a blow to the MFDC while it counted as a score for Senegal. Immediately, the new president, Adama Barrow was sworn-in, Senegal quickly stretch hand of friendly relations to the state as means to a diplomatic end. On the role played by Senegal during the 2016/2017 political impasse in The Gambia, Omotosho \& Senghore, (2018) averred that Senegal could be accused of primordial intents for being too inquisitive on intervention by taking advantage of prevalent circumstances to implement actions for her national interests, while, influencing the Big Brother Nigeria with enormous power and influence on the ECOWAS to lead, the intentions known to Jammeh long ago and which made him never to be in agreement with Senegal as long as he remained in power as Gambia's Head of State. This signals Senegal's primordial interests and hegemony, if not, political control of the Gambia.

Besides, a cue from Senegal diplomatic game with other neighbouring states like Guinea Bissau would lend credence to my argument that Senegal involvement with Gambia is largely influenced by the realists' orientation. To achieve its interest, Senegal considers other neighbouring states in its diplomatic game and Bissau is not left out. The diplomacy Senegal (Under President Wade) deployed in Bissau to force a regime change is apt in the case. Foucher (2013) while analysing the basis of Senegal's involvement in Guinea Bissau politics, also noted that such relations under Wade regime was informed to secure Bissau, through change of government, the management of Casamance crisis, which for decades had been Senegal's greatest issue.

\subsection{Territorial and Geographical Influence}

The geographical and territorial peculiarities of the two neighbours have over the years left them with no option than to forge cooperation which can best serve their respective national interest. Geography has been one of the most potent factors influencing the continuities of the two states relations. On geographical determinism, Panikkar (1957), averred that "pacts may be broken, treaties unilaterally denounced, geography holds its victims fast' That is, a nation can escape anything but geographical influence. Gambia and Senegal can compromise other factors, but not influence of geography. The Gambia is almost entirely surrounded by Senegal on every side with exception of its Western coastline along Atlantic Ocean (Hoare, 2002). For Senegal, it's almost bifurcated into two equal sizes by Gambia. In fact, the Senegalese southern province of Casamance is separated from the rest of the state by Gambia. Given this inherited colonial boundaries, the two states naturally see the 
need for a continual friendly relations for protection of their respective territorial integrity and to ensure national survival.

The strategic importance of Gambia to Senegal accounted for the public declaration of the elected President Sall's first Press interview in 2012 where he stated that "This (Casamance) is Senegal's greatest problem. It lasted for 30 years - 30 years of destruction, death and spilt blood. It's high time to mobilize all our resources to achieve a sustainable peace in Casamance. I will make my number one priority the creation of the conditions that can produce a national dialogue between all the parties concerned: the guerrillas, Senegalese civil society, and friendly neighbouring countries who are in fact caught up in the conflict because their territory is being used by the rebels, either in Gambia or ..."(Freedom Newspaper Online, 2012). Thus, regardless of the arbitrary boundaries between of the 1889 Anglo-French Agreement, which has plunged the two states into border tension, they still see the possibilities of harnessing their disadvantages for mutual benefits and peaceful co-existence.

\subsection{Socio-Cultural Affinity as a Means to an End}

The socio-cultural dichotomy that resulted out of the colonial occupation in West Africa and by extension, Africa continent has caused diverse kind of inter-state armed conflicts and strained inter-state relation. Ethnic polarity is one of the dangerous legacies of colonial expedition in Africa as whole. The arbitrary demarcation between The Gambia and Senegal is the most ridiculous in Africa (BBC News, April 2016). People with similar socio-cultural features were separated and at independence, most of the African states could not harness the difference for mutual advantage. Gambians and Senegalese commonly describe themselves as "one people" in two states. They foster claims of kinship, blood ties, and a shared culture (Khan, 2017). Regardless of colonial rule and legacies, Gambians and Senegalese nurtured identical value systems with commonly accepted norms like "integrity and noblesse oblige (gor), self-respect (njom), politeness (Keursa), empathy and being one's brother's keeper (ndimbalante)." "These values are further reinforced and propagated in the extended family, kinship or clan organisation referred to as KeurinWollof, KabiloinMandinka and Galle in Pulaar" (Ibid. 2017). These peculiar features of Senegambia society makes it easy for outsiders, including "migrant labourers (tilibonkas or navetanes) and itinerant Muslim traders and clerics" to settle down "temporarily or permanently in most areas of Senegambia.”(Renner, 1985)

Besides, there exists religious unity between Gambians and Senegalese. Cross-border religious groups have membership from both sides of the border. Also, there has been an age-long practice where Gambians receive religious education in Senegal or Senegalese do the same thing in The Gambia. This practice ensures long-term intergenerational family links. From the Trans-Saharan trade to modern times, religion and commerce have been closely intertwined in the Senegambia region. Cross-border mobility for religious reasons has been an important market for cross-border transport. Moreover, cross-border religious actors include cross-border traders, and /or transporters. Cross border economic and religious interactions are functions of socio cultural affinities (Babou, 2007). Cross-border ties between the two populations are ensured, reinforced by language, kinship ties, modes of economic exchange and lifestyles.

On this basis, it has been argued that Colonial dichotomy did not redefine in any major way the ancient bloodlines, family-ties, the ethnic composition and shared cultural and religious value systems of Gambia and Senegal. It is also argued that these homogenous components have been used to diffuse the border tension between the two states; certain socio-cultural notions are sometimes invoked to de-escalate interstate conflicts on the border. These notions have been argued to have transformative effects on interstate tensions and increased the economic interactions between them and informed a functional political union between the two states at a point. But it is instructive to point out that the acclaimed socio-cultural affinity as the basis for continuity in the Gambia-Senegal relations failed to foster and sustain the political union in the case of the defunct 1982 confederation. On this, Hughes and Perfect (2008) averred that there were Gambians, and of course Senegalese, who opposed the Confederation on the basis that the two countries were in fact different. These critics saw the Confederation as Senegal's attempt to use ethnic affiliations as an excuse to dominate its smaller neighbour, The Gambia. This view fuelled Gambian nationalist sentiments against the Confederation and paved way for its demise in 1989.

No doubt, colonial dichotomy played out when the separated nations attempted to come together. They saw their 'differences'. The socio-cultural sentiment triggered economic and political fear on the part of the small state of future domination by Senegal. The failure of the confederation was brought about majorly by inability of the two states to reach agreement on monetary and economic union. The Gambia unwilling to compromise its sovereignty (Political and Economic independence) and the Senegalese refusal to assume Gambia security without corresponding economic and political concession lead to the eventual collapse of the union (Touray, 
2000). However, the acclaimed socio-cultural homogeneity of the two states remains a rallying point for the furtherance of their respective national interests beyond the collapse of the confederation in 1989.

\subsection{National Security}

National security is central to national development and sustainability of any nation, developed, developing or under-developed. The quest for national security in form of defense of territorial integrity is an uncompromised value that influences any nation foreign relations. The case of Gambia-Senegal is not an exception in this regard. This factor has always informed The Gambia to cultivate high degree of mutual understanding and friendly relations with the government of Senegal. The reasons are not far fetch. The country's geographical lay out is bordered on the north, east and west of Senegal and that may easily threaten its security (Addae 2003). Arnold and David (2008), opined that in achieving the core value of The Gambia's foreign relations, the country's various governments are determined to defend the country's sovereignty and territorial integrity. This involved attaining its independence from Britain and defining an effective relationship with Senegal. It also necessitated adequate military defence for the survival of the territorial integrity of The Gambia and to maintain internal security. On its part, considering the nature of its Strategic location (as seen in the map above), Senegal sought to keep the Gambia from becoming both a safe haven for Senegalese dissidents and a base for the Casamance rebels. Thus, cordial relations between the two states are the calculated means to an end (national security). None of the two states is ready to compromise their national security for any reason. For the Gambia, the importance the state's relations with Senegal depend on capacity building and in the sense of security that they gave each other. This is why in 1970s, the confidence between the two states deteriorated having considered each other as national security threat; the Gambia considered Senegal a threat to its territorial security, and Senegal considered Gambia as threat to its economic security(Touray, 2000:99).

The Gambia, its concession for Senegambia confederation in 1982 was basically a means for greater national security which could only be guarantee at that time by such concession. The 1981 military coup threatened the Gambia national security and it has no option left than to enter external defence agreements with Senegal particularly, given the Senegalese prospect and motivation to salvage the situation (Arnold \& David, 2006, Jeggan 2012 \& Arnold, 1992: 207-208). The Gambia-Senegal relations can be best appreciated and understood when viewed from the security angle. The Senegalese intervention and roles played in aborting military coup of 1980/1981 in the Gambia under the late President Dawda Jawara, and efforts geared during the 2016/2017 political impasse to restore normalcy in the Gambia through ECOMIG undoubtedly pointed the close ties between the two and the security dimension of these relations. The Gambia see a continual relations with Senegal as means to territorial and national security, and the Senegalese motivations and willingness to offer a protector role as means to economic security and avenue to advance its hegemonic gesture.

\subsection{Economic Interdependence}

Karl Mar (1845) while explaining economic determinism (Dialectic materialism) used an architectural metaphor to explain the forces that bring changes in the society. In his explanation, he likens economy to sub-structure as determinants of other forces such as politics which he called the superstructure. To Marx, change and continuity in the society either in terms of human or group relations is embedded in economic interactions. To understand the ways and process of societal interactions with their surroundings and development is predicated on understanding of the economic forces in the society. Beyond socio-political forces which appear on the surface as forces pulling the Gambia and Senegal into continual relations, there are silent but salient mutual economic forces that continue to grease their friction. The two states are bound by economic mutualism which has facilitated their relations over the years.

Given the location and size of The Gambia, all of its land trade is with or via neighbouring Senegal, and much of which involves transit and re-exports operations. Given the paucity of sea and air freight, most goods passing from northern Senegal towards the southern part, or beyond, must pass through The Gambia or make a long diversion (Economic Intelligence Unit Forecast Report, 2016). Similarly, The Banjul port is relatively underdeveloped and thus not well-placed to compete with Senegal as regards the servicing of trade with other countries. As such, Gambia must recognize the landlocked countries in the neighbourhood and such make the most of whatever opportunities it gets to acts as a trade intermediary. The understanding of the economic indispensability to each other however accounted for border diplomacy by the leaders of the two states especially during the regimes of Presidents Sall of Senegal and Jammeh of The Gambia. In fact, the 2016 Senegal-Gambia border closure and the accompanied economic effect on the two states and the neighbouring state of Guinea Bissau further put the economic interdependence of the two states in perspective. The border closure affected road transport particularly commercial taxis and trucks transporting goods, greatly hampering trade between the 
two neighbours. The border closure slowed down economic activities in the two states for weeks before President Alpha Conde of Guinea Bissau mediated the border issue and the border was eventually opened for free flow of economic activities again (Jobe, 2016).

\section{Conclusion}

"...I believe that He will prosper most whose mode of acting best adapts itself to the character of the times; and conversely that he will be prosperous, with whose mode of acting the times do not accord" -Niccolo Machiavelli (1909-14: 25)

The above summation by the realist thinker lends credence to my contention that the continual relations between Gambia and Senegal amidst the anarchic colonial dichotomy are a function of derivative national interest. Evidently, the colonial legacies played out in their relations, but their respective national interest act as a bridge. The border conflict between Gambia and Senegal is a direct implication of the arbitrary boundaries created by colonialism. The border tension have continuously threatened the relations between the two states on different instances, but the two states have always find ways around their differences to maintain a balance in their relations and remain at pal. In international system, however, no state relates in vacuum. The interactions with either state or non-state actors are predicated on chain of forces which can be external or internal.

In the Gambia-Senegal relations, there were period of strained and smooth relations, but continuity has been a function of mutual interests and efforts influenced by hegemony, geographical, security, socio-cultural and economic underlying forces which have been over the years put the colonial dichotomy on check. The Gambia in particular, considering its enclave nature (inside Senegal), should guard her sovereignty jealously from her immediate sister French nation, which is a longstanding channel for France economic interest in the sub-region. Also, Gambia should be awake to the reality of international politics (power politics) which has no fibre of morality, and such should spread its multilateral diplomatic tentacles beyond the border of Senegal through dynamic foreign policies - even as they both maintain friendly relations. It should not be carried away by the kingship metaphor of "oneness" which Senegal has been using to pursue its politics of patronage and hegemonic tendencies in the sub-region. And for Senegal whose continual presence and political intervention in Gambia signals political control, should respect the sanctity of the latter's sovereignty regardless of its size. Else, the growing suspicion of Senegal's political and economic motive in The Gambia may generate public opinion and consequently strain the Gambia- Senegal relations in the future, considering the already planted colonial seeds of discord between them which only await a slight plash of 'water' to manifest.

However, here lies a lesson for other Africa countries that are entangled and constrained by similar 'colonial messes'. In every disadvantage, lies an opportunity. Gambia and Senegal realised their colonial disadvantages and consciously explored them through fence-mending diplomacy to advance their respective national interest in a mutual atmosphere. Other African countries are thus encouraged to follow suit and refrain from breeding on colonial inheritances which has been a factor to myriads of border-related disputes in the continent. Conscious efforts should be geared towards the exploration of the numerous opportunities that lie in the colonial dichotomies that exist between African nations for mutual growth, national development, and by extension, continental peace.

\section{References}

Addae, P. (2003). Comprehensive notes on West Africa political and constitutional development for the Gambia, Last Bundung: Fatoumatta's Print \& Communication Centre, 2, p.187.

Arnold, H, (1992), The Collapse of Senegambia confederation: The Journal of Commonwealth and Comparativ e Politics. 39 (2), 200-222.

Arnold, H., \& David, P. (2008), The historical dictionary of the Gambia $\left(4^{\text {th }}\right.$ ed.). New York: The Free Press.

Arnold, H., \& David, P. (2006). A political history of the Gambia, 1816-1994. Rochester, N.Y.: University of Rochester Press.

BBC News.(2012), “Gambia executions: Senegal anger after nationals killed,” 29 August 2012," Retrieved May 19, 2019 , from. http://www.bbc.com/news/world-africa-19407911

BBC News.(April,13, 2016), Senegal Truckers Tired of taking the Long Way Round The Gambia. Retrieved May 19, 2019 , from http://www.bbc.com/news/world-africa-36025182

Carr, E.H. (1946). The Twenty Years' Crisis, 1919-1939: An Introduction to the Study of International Relations. ( $2^{\text {nd }}$ ed.) London 
Cheikh, A. B. (2007).Fighting the greater Jihad: Amadou Bamba and the founding of the Muridiyya of Senegal, $1853-1913$. Athens: Ohio University Press.

Darbo, L. B. (2011). Senegal-Gambia border, other issues top assembly adjournment debate, The Point Newspaper. (Online) Retrieved April, 2019, from (http://thepoint.gm/africa/gambia/article/senegal-gambia-border-otherissues-topassembly-adjournment-debate

Dunne, T. \& Schmidt, C.B. (2005). Realism in Baylis, J. Steve, Smith S. \&Owen, P.(2005). Globalization of World Politics: An introduction to International Relations. Oxford: Oxford University Press. PP. 141-161

Economic Intelligence Unit Forecast. (2016). Gambia and Senegal Signed trade understanding. Retrieved June 2019 from http://www.eiu.com

Ernest, M.(1976). Introduction to Karl Marx, capital. 1 . Harmondsworth, U.K: Penguin p.18.

Foucher, V. (2013), Wade's Senegal and its Relations with Guinea Bissau: Brother, Patron or Regional Hegemon. Occasion Paper No. 132. South African Institute of International Affairs

Freedom Newspaper Online.(2012). $\quad$ Retrieved $\quad$ May, $2019 \quad$ from http://freedomnewspaper.com/Homepage/tabid/36/mid/367/7417/Breakin,

Godfrey M. (2010). The Gambia, and its people, ethnic identities and cultural integration in Africa. Dares Salaam:New Africa Press.

Golvin, L. G.(1975). International relations in pre-colonial senegambia. Presence Africaine Nouvelle Serie, 93, 215-230.

Hans, J. M. (1966). Politics among Nations ( $4^{\text {th }}$ ed.). New York: Alfred A. Knopf.

Hoare, B. (2002). The kingfisher A-Z encyclopedia. Kingfisher Publication. P. 11

Ieuen, G. (1996) 'Permeable Boundaries in Africa', in African Boundaries, Barriers, Conduits and Opportunities, ed. Paul Nugent and A I. Asiwaju. New York: Pinter.

Jeggan, C.S. (2008). The politics of Senegambia integration, 1958- 1994. Bern: Peter LangAG, International Academic Publishers.

Jeggan, C.S. (2012), Senegalo-Gambia Relations: Continuities in the past and Future, Panbazuka News, May, 08, 2012 Retrieved, March, 2019, from http://www.panbazuka.org/governance/senegalo-gambia-relations-continuities-pa st-future.

Jeng, A. (2017), The Casamance conflict how and why did the MFDC lose the battle for independence?. Dalarna University Open access Publication. Pp. 14

Jobe, A. (2016), President Conde mediates in Senegal Gambia border closure, The point newspaper. Retrived May 2019, from http://thepoint.gm.africa/gambia/article/president-conde-mediates-in-senegal-gambia-border-closure

Jordan, A.Z (1967). The Evolution of Dialectic Materialism. London: Macmillan Publisher .pp. 167

Khan, Mariam (2017), "Blood neighbours" and border enemies: Transport, trade, talibee networks and The Gambia-Senegal relations, 1960-2015. MPhil Thesis in African Studies Program submitted to University of Edinburgh, Scotland.

Lamin, S. (2019).Senegal-Gambia Relations; Going a higher notch. The Standard Newspaper, The Gambia. Retrieved April, 2019, from http://standard.gm/senegal-gambia-relations-going-a-higher-notch-higher/ Lasswell, H.D.(1936). Poltics: Who gets what, when, how. New York: Whittlessey House, 3(6).

Machievelli N. (1909-14). The Prince. The Harvard Classics.36(1) . New York: P.F Collier\&Son. P.25 Retrieved May, 2019, from http://www.bartleby.com/36/1/

Marx, K. (1845). The German ideology, Selected Writings, p 12o Retrieved May, 2019, from http://www.marxist.org.

Omotosho, F.O. and Senghore, A.A. (2018). The Gambia and the 2016/2017 political impasse: An impact assessment of the peace and security implications on the nation's economy and the international legal justifications for/against ECOWAS intervention, January, 2017- February, 2018. International Affairs and Global Strategy, 63, 44-54.

Panikkar, K.M (1957,). The Principles and practice of diplomacy, p.71, cited by Prackash Chandra, The theories of International Relations, third edition, P.113.

Renner, A. (1985). Ethnic Affinity, Partition And Political Integration In Senegambia, in Partitioned Africans, Ethnic Relations Across Africa's International Boundaries 1884- 1984, (ed.). London/ Lagos: C. Hurst and Company/ University of Lagos Press,),

Touray, Omar (2000), The Gambia and the world; A history of foreign policy of Africa smallest state, 1965-1995. Hamburg; Institute for Afrika-Kunde

Walt, S. M. (1987), The Origins of Alliance, Lthaca:Cornell University Press.

World Population Review. (2019). Retrieved May, 2019 from http://www,worldPopulationreview.com/countries/gambiapopulation/. 